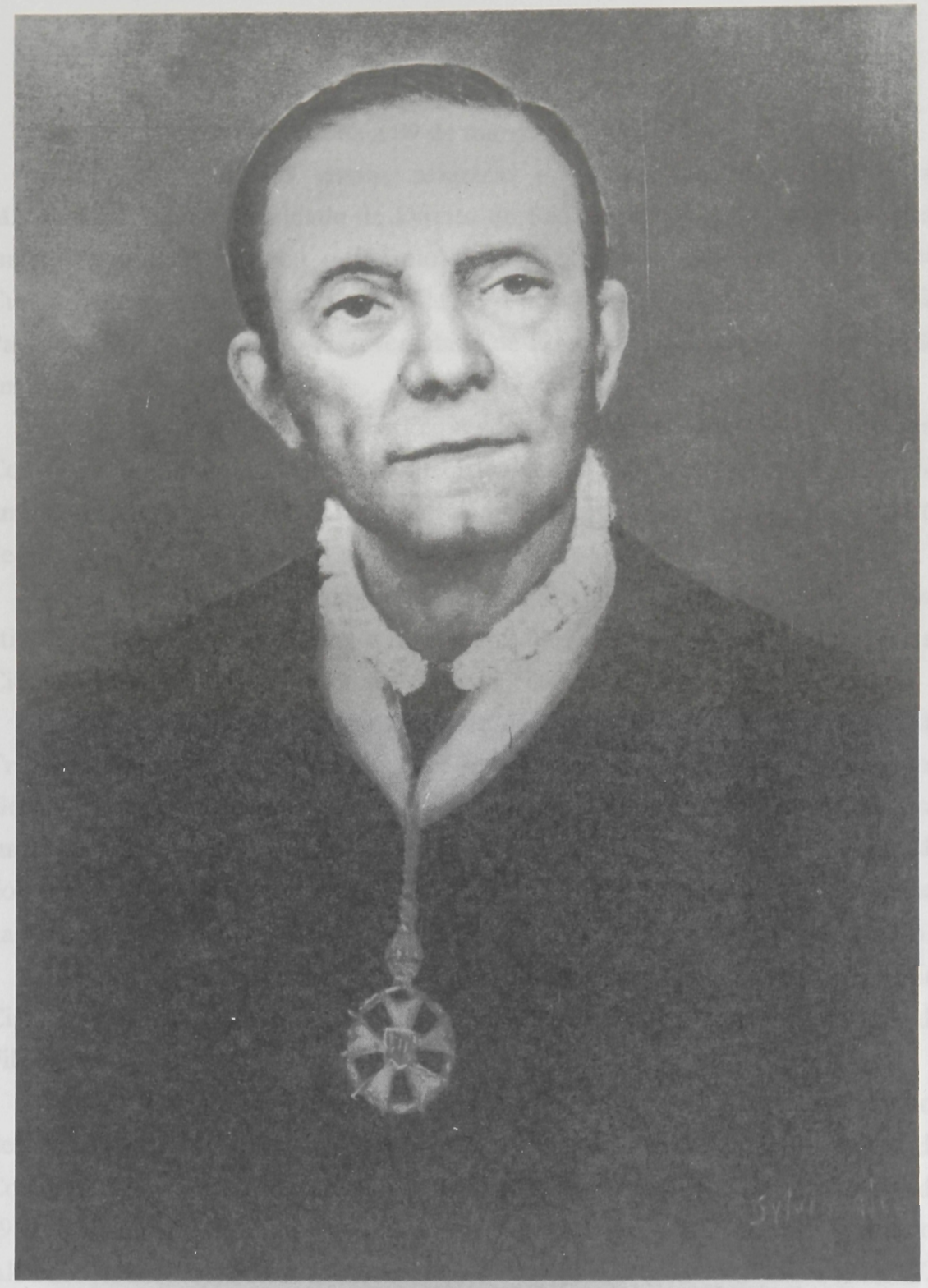

J. PINTO ANTUMES 



\section{JOSÉ PINTO ANTUNES}

(1969-1973)

Nasceu em Lorena a 09 de março de 1906.

Concluiu os cursos primário e ginasial em sua terra natal. Matriculando-se na Faculdade de Direito de São Paulo em 1924, bacharelou-se em 1928, quando recebeu o Prêmio Rodrigues Alves como primeiro aluno. Cursou simultaneamente a Faculdade de Filosofia, Ciências e Letras de São Paulo, agregada, na época, à Universidade de Louvain, tendo obtido a graduação em Filosofia no ano de 1926.

$\mathrm{Na}$ esfera política, participou das lutas cívicas durante o Movimento Constitucionalista pelo Partido Democrático, tendo sido seu secretário geral. Foi um dos fundadores do Partido Constitucionalista, pelo qual, em 1934, foi eleito deputado à Assembléia Constituinte de São Paulo.

Implantado o Estado Novo, abandonou a política e reiniciou suas atividades culturais. Fez os cursos de doutorado em direito nesta Faculdade e em Ciências Sociais e Políticas na Faculdade de Filosofia da mesma Universidade.

Em 1941, conquista a cátedra de Direito Industrial e Legislação do Trabalho na hoje Faculdade de Direito da Universidade Federal de Minas Gerais. Aí permanecendo até 1956, lecionou também Economia Política no curso de bacharelado e Economia Social e Legislação do Trabalho no curso de doutorado. Nesse período conquistou a livre-docência de Direito Constitucional na Faculdade Nacional de Direito da Universidade do Brasil, no Rio de Janeiro.

Fundou em sua terra natal a Faculdade Salesiana de Filosofia, Ciências e Letras, onde foi titular da cadeira de Psicologia Racional, na seção de Filosofia.

Em agosto de 1956, concorreu à cátedra de Economia Política desta Faculdade, obtendo o primeiro lugar. Participou, a partir de 1963, do Conselho Técnico da Faculdade e do Conselho Universitário. Em princípios de 1969, exerceu a vice-diretoria e com o afastamento do então diretor professor Alfredo Buzaid, assumiu a diretoria efetiva, aí permanecendo até 1973. Em 1972, durante sua gestão, foram instalados os cursos de pós-graduação, de acordo com as diretrizes estabelecidas pela reforma universitária. 
Foi membro da Sociedade de Estudos Econômicos, da Sociedade de Etnografia e Folclore, do Instituto Histórico e Geográfico da Bahia, da Ordem dos Advogados de Minas Gerais e do Instituto de Direito Social de São Paulo. Possui diversos artigos publicados nas Revista Forense e Revista do Trabalho.

Faleceu a 13 de abril de 1975.

\section{Obras Publicadas}

Raciocracia, forma scientifica de governo. São Paulo : Revista dos Tribunais, 1933.

A philosophia do Estado moderno. São Paulo : Revista dos Tribunais, 1934.

A philosophia da ordem nova: a questão social e sua solução. Rio de Janeiro : José Olympio, 1938.

Do sindicato operário: apogeu e decadência. São Paulo : Revista dos Tribunais, 1939.

Os direitos do homem no regime capitalista. São Paulo : Revista dos Tribunais, 1947 (dissertação de concurso).

Da limitação dos poderes. São Paulo : s.c.p., 1950.

A produção sob o regime da empresa: as razões da iniciativa privada, economia e direito. São Paulo : Saraiva, 1964. 